\title{
Conventional Female Images, Islamization and its Outcomes: \\ A study of Pakistani TV Dramas
}

\section{Saleem Abbas, Forman Christian College, Pakistan}

\begin{abstract}
This paper explores the dichotomy of a "good and bad" woman in the portrayal of Pakistani TV dramas telecast during the period of 'Islamization' (1977-88) in Pakistan. This era witnessed the integration of Islam into politics and constitutional structure. The construction of a 'good woman rhetoric' through TV dramas played a significant role in reinforcing stereotypical and traditional views and attitudes about women. In the wake of the War on Terror, the issues of gender equality and women representation have gained considerable attention for Pakistan. I examine two drama serials, selected on the basis of purposive sampling. Through the analysis of discourse in dialogues, roles assigned to women, and the ways of addressing them, I argue that dramas in Islamization period depict images of women that are highly conservative; this kind of rhetoric has a significant role in the provision of a gauging parameter for women's conformity with established norms.
\end{abstract}

Keywords: Islamization, Zia-ul-Haq, Women Portrayal, PTV Dramas, Pakistani Women, Gender inequality, 


\section{Introduction}

After 9/11, the issues of terrorism and radicalism have become very important for Pakistan with day by day increasing complexity. Pakistani state-controlled media is often blamed to spread conservative ideas in 1980s. In this paper, I study the genre of TV drama serials, which have been a popular source of entertainment and find the connections of conservatism back to the martial-law of Zia-ul-Haq. I analyze the content of Pakistani TV dramas to explore the rhetoric of women representation generated in the Islamization period. In Pakistan's historical formation, Zia is known for triggering the process of Islamization for the country. This period can be well described in the words of Hamid (2015) in Discontent and its Civilizations: Dispacthes from Lahore, New York, and London. Hamid has stated that in the pursuit of Islamaization Zia thought that “our Islam wasn't Islamic enough indeed that we Muslims weren't Muslim enough" (p. 23). Thus, this period initiated the integration of religion into Politics for Pakistan.

Zia did vast legislation, changed the judicial system and used national media for his promotion as a 'Solider of Islam'. According to Naqvi (2017), "In the 11 years of rule, Zia not only wielded absolute power but also altered the political and societal fabric of the country." Like most dictators, he, too, was not a visionary person and just wanted to prolong his tenure with the support of strong religious parties. Many scholars (Hasan, 2000; Haqqani, 2005; Rashid, 2012; Shah, 2014) argue that the entire period of 'Islamization' provides the base of many societal, national and international issues like religious intolerance, guns and drug culture, male chauvinism, gender inequality and the issues of women rights. In order to examine the links between these issues and the legacy of Zia ul Haq, it is important to examine the functioning of Pakistani media in his regime.

This paper explores how women are portrayed in TV dramas during General Zia ul Haq's martial law. Moreover, it discusses the rhetoric of a "good woman" which was projected through this popular TV genre. Through qualitative content analysis, this study examines the role of Pakistani TV dramas for projecting the archetypal and traditional roles assigned to women in society. According to Author (2010), TV drama is one of the most popular sources of entertainment and an effective tool of communication in Pakistan. During 1977 to 88, Pakistani TV dramas were very popular all over the country. Thus, I have chosen two drama serials, i.e., Waris (The Heir) and Mirat-ul-Uroos (The Bridal Mirror) and examine the 
issues related to gender equality and women rights, which have been prevalent in Pakistani society. Although a number of gender inequality issues are associated with Islamization period; some examples include the promulgation of the Hudood Ordinance, Chadar aur Chardiwari (veil and within the walls of home), Hijab, the law of inheritance and the law of witness, however, through the analysis of dramas, I specifically study the submissive roles assigned to women, their responsibilities confined to household chores, and conventionality in their dresses. It is significant to note that Zia regime policies were not only considered to be intrinsically misogynistic but are also blamed to promote a patriarchal mentality among people.

Speaking of the role of media in Pakistan during Islamization, it is important to consider how propaganda works in social formations. In terms of propaganda, Chomsky describes the power of media quite well. Chomsky (2002) mentioned in Media Control: The Spectacular Achievements of Propaganda that governments spend billions of dollars every year just to control the public minds. He further argued that:

You don't want people to think about the issue. That's the whole point of good propaganda. You want to create a slogan that nobody's going to be against, and everybody's going to be for. Nobody knows what it means, because it doesn't mean anything. Its crucial value is that it diverts your attention from a question that does mean something: Do you support our policy? (p. 26)

This is relevant to media propaganda in Zia's period. He propagated the slogans of Islam and used them for the longevity of his military reign. Pakistan Television (PTV) was the only channel in the country until 1992. As a state owned TV channel, PTV served as a major tool of state propaganda. So we can observe the rhetoric of Islamization in TV dramas, too.

Although the founder of Pakistan, Muhammad Ali Jinnah had no intention of making the country religious, Jalal (2015) argues that the subsequent rulers of Pakistan have used religion for their own political gains (a lecture at 'UNE Center for Global Humanities'). In order to gain popularity among conservative-leaning folks, Pakistani rulers took steps towards 'Islamizing' the country. Some of such initiatives included changing county's name from 'Pakistan' to 'Islamic Republic of Pakistan', legislation of Islamic laws, formation of the Council of Islamic Ideology, introducing the Ministry of Religious Affairs, prohibition of 
alcohol and night clubs and excluding the Ahmadi- community from the circle of Islam (Shah, 2014, p. 115).

A number of scholars (Haqqani 2013; Jalal 2014; Paul 2014; Hamid 2015; Hijari 2016) consider Zia to be responsible for turning Pakistan into a global center for political Islam. Haqqani (2013) mentioned that "Zia went farthest in defining Pakistan as an Islamic state, and he nurtured the jihadist ideology that now threatens to destabilize much of the Islamic world" (p. 88). His policies are predominantly symbolic and political than religious (Maskiell 1984; Shah (2014). Hassan (2000) has argued about Zia-ul-Haq that, "He banned Quaid-eAzam's historic speech $^{1}$ on media, which was the Magna Carta for a secular Pakistan" (p. 184). In addition to that, in Pakistan, the issues of feminism became intense in Zia-ul-Haq's regime and came to attention in the wake of the war on terror. For example, consider what Saigol (2016) has argued in "Feminism and the Women's Movement in Pakistan: Actors, Debates, and Strategies"; it deserves to be quoted here at length. She wrote:

With a relentless focus on piety in the private sphere and control over the personal lives of citizens, an inordinate amount of attention fell upon women who were seen repositories of culture, religion, and tradition. The veil and the four walls were emphasized, piety in dress codes was imposed by vigilantes operating in the public sphere, and violence was used to ensure compliance with official measures. (p. 14)

Saigol argued about the use of force and oppression against women in Zia ul Haq regime. Similarly, I explore the propagation of similar ideas through the projection of good women versus bad women.

The construction of a 'good woman rhetoric' through media played a significant role in reinforcing stereotypical and traditional views and attitudes about women. While mentioning the legacies of martial law decade, Zia (2009) discussed that, "The only tool of analyzing women in Pakistan is faith-based politics and a woman's acceptance or resistance to expressions of this politics" (p. 30). This reveals that the issue of feminism cannot be

\footnotetext{
${ }^{1}$ Speech of Quaid-e-Azam Muhammad Ali Jinnah (the founder of Pakistan) at inaugural session of the first Constituent Assembly on 11 August 1947. "You are free to go to your temples, you are free to go to your mosques or to any other place of worship in this State of Pakistan. You may belong to any religion or caste or creed__ that has nothing to do with the fundamental principle that we are all citizens and equal citizens of one State" (Hasan 2000, p.188).
} 
separated from politics in Pakistan. Thus, in order to situate feminist issues in the women portrayal of Pakistani dramas, it is important to consider political instability the country had been through.

Talib and Idrees (2012), studied post Islamization period and discussed the current role of media (especially soap operas and daytime talk shows) which is contributing towards women disempowerment. They added that the major characteristics of current broadcast and print media is its reliance on Pakistani traditional cultural narratives, which are portrayed through media. For example, validations of womanhood through matrimony, rescuing the frail maiden and denigrating women who violate chader and chardiwari. Similarly, Kothari (2005) found that a patriarchal and discriminatory form of Islam was promoted in the form of Charadr and Chardiwari through Urdu drama serials, which confines females to their homes. She has argued:

Islamist ideology in Pakistan constructs the home as the domain of feminine expertise. While given a certain power in this location, woman is also confined to this space. This hegemonic limitation of a woman's agency is both celebrated and critiqued by Urdu serials, providing viewers with both identification and escape (p. 296).

It appears that there is a dearth of research on the study of Urdu drama serials of the Zia-ulHaq regime to explore dramas' roles for perpetuating stereotypical women roles. At the time of Zia's military coup, Pakistani dramas were immensely popular. It appears that Zia administration used the same medium for the propagation of state sponsored ideologies. His government affected the television transmission to such an extent that the entire pattern of PTV programs was changed. Hasan (2000) stated that "he banned all dance and pop music programs and increased the number of religious programs" (p. 196). My research, however, specifically studies this effect on women representation in Urdu drama serials broadcast by PTV. To analyze this representation, this article focuses on following three assumptions (for the selected drama serials): (a) Women are portrayed in acquiescent roles, (b) Dramas describe women as a primary caregiver for children, and (c) the conventionality in dresses is highly projected as a positive attribute for a 'good woman rhetoric'. 


\section{Methodology}

I use the method of qualitative content analysis to examine two popular Urdu drama serials i.e., Waris (The Heir) and Mirat-ul-Uroos (The Bridal Mirror). In order to have a comparative overview, I chose former from the beginning of Zia regime-Waris (1979) and the latter from the end of this time period-Mirat-ul-Uroos (1988). I choose scene-in which women are portrayed - as a unit of analysis for this study. Thus, I analyze 419 scenes in total.

My research entails following research questions:

- Is a woman's submissiveness towards male family members appreciated?

- Do dramas exhibit dominating female character/s in husband-wife relationship?

- In a husband-wife relationship, who takes the responsibility to look after children?

- Are women encouraged to go for their professional career?

- Female characters are portrayed in what kind of dresses (conservative, moderate and westernized, etc.)?

\section{Operationalization of the Categories:}

I conceive categories in my research questions as follows:

1. Submissive. This category applies if a female character shows obedience to the male members of her family (i.e. father, husband or brother.); she does not argue with them, does not talk-back or questions their authority. Besides this, if she always gives importance to male members' opinion and does not raise her voice in front of them.

2. Dominating. A female character is considered dominating if she decides family matters in the presence of her husband; always talks to the opposite male character in a firm tone; yells on male members of her family; argues or fights for her opinion.

3. Domestic/House wife. In this category I examine whether a character appears to stay at home, lives a non-professional life; takes care of the house; does not do any job for earning. The woman will be considered house-wife or domestic, even if she goes out to help her husband in his job. For example, in rural areas, women work with their male family members in fields during harvesting seasons. All those unmarried girls are also included in this category who stay home with their parents.

4. Child Caregiver. I use this category to find out if a character cooks food for her children, feeds them, babysits and helps them to do daily activities. 
5. Professional career. In this category, I include the character who works in any professional field to earn her living such as teaching in an educational institution, working in a hospital as a medical officer or paramedical staff, serving in a restaurant, etc. Getting education and preparing herself for any specific profession also include in this category.

\section{Dressing.}

Conventional Dress. This sub-category shows if a character appears in a lose fit Pakistani dress like Shalwar qamiz or Shalwar kurta with full sleeves and scarf /shawl or head covering.

Moderate Dress. This category applies if a character appears in a slim fit Pakistani dress with full or short sleeves, i.e. shalwar and a long shirt but without any scarf or head covering. Sari is also included in this category.

Westernized Dress. This sub-category applies if a woman appears in shorts, pants, jeans, tights, no head-coverings (dupatta) with any kind of dress shirt, T-shirt or tops.

\section{Islamization through PTV Dramas}

Pakistan is among those countries where patriarchy has deep roots in society. Being a male dominated society, the majority tends to prefer sons over daughters and male gender is intrinsically superior to female folks. This mentality has passed over generations. Pakistan was declared an Islamic country by its subsequent rulers. Thus, gradually these cultural norms and traditions have got a religious label on them.

\section{Acquiescent Roles for Women}

Waris, a blockbuster drama serial of 1979-80 has 21 different female roles. All these characters portray women in weak or submissive roles. These characters represent different rural and urban women who don't have their own identities. Zubaida, and Sughra belong to a landlord and elite class of the country. Zakia and Seemi represent urban middle class, whereas 'Zohra' and 'Jiran' symbolize rural lower working class. The drama has a complex plot and reflects the male dominating society of Pakistan. All tracks of this drama serial move around prominent male characters. The central idea of the plot deals with an old feudal lord Chaudhry Hashmat, whose ancestors served the British and received lands as a reward. Now, he stands among the most influential lot of the country. The government wants to construct a 
dam in his region. But he does not want to lose his subjects whom he has been ruling for generations. Therefore, he becomes a staunch opponent of the dam and adopts all the unfair means to prevent its construction. The story of second track evolves with the character of Chaudhry Yaqoob, who is the son of Chaudhry Hashmat. Yaqoob is a shrewd businessman and wants to attain all the property of his father. His wife 'Zubaida' is a typical house-wife, who does not take part in her husband's business matters. She always follows his instructions. If, at times, she has a different viewpoint, she cautiously raises concerns, but easily retreats in front of Yaqoob's tricky arguments.

Another track of the drama is associated with 'Moladad' and 'Dilawar'. They both are the most trusted and brave workers of Chaudhary Hashmat. Moladad's wife Zohra is presented as a simple, good looking but terrified village girl. She, too, plays a submissive role in the drama. There are two aspects of her role: (i) a loving and docile wife who stays home and waits for her husband, and (ii) a caring and affectionate mother. Although she is referred at various places in drama, her appearance is little on the screen. Zakia is the daughter-in-law of Chaudhary Hashmat and the widow of his deceased son Ghulam Ali. She is an educated lady who has no blood relation with the family of Chaudhary Hashmat. By nature, she is a kindhearted and modest figure who is living alone with her son Farrukh. In order to escape the evils of Chaudhary Hashmat, she works as a principal in a school and supports her son's education in a university.

In this drama serial, Zakia's role is very prominent. She performs the role of an affectionate mother, a sacrificing wife, and a widow at the same time who is mainly dependent upon her late husband's brother; she is a loving daughter, too, whose father disappears twenty-five years ago. She tries to refrain from quarrels and conflicts and doesn't want any impact of Chaudhary Hashmat on her house. She speaks graciously in accordance with her role and wears a graceful dress. She takes care of her father Shan Mohammad. Towards the end of drama serial, when Chaudhary Hashmat tells her that he intends to make Farrukh his legal heir. She doesn't get overwhelmed and declares that she doesn't need his money. This suggests her contentment as a character in the drama serial. Sughra, a wife of Chaudhry Niaz is also a suppressed character. She is graduated from a best college of Lahore and now after her marriage, confines herself in a big Haveli (farmhouse) at Sikanderpur. Sometimes she 
feels herself enslaved in a big castle, which has no way-out. In spite of her feelings, she always shows respect and obedience to her husband and all other male family members.

The drama serial Mirat-ul-Uroos (1988) is derived from a popular Urdu Novel written by M. N. Ahmed in 1869. The writer stresses upon education and household training of women. This novel was used as a book of guidance and inspiration for Muslim families. Ahmed endorsed women education for an active role in the development of society. He particularly stressed on the Muslim females, the majority of whom were illiterate at that time, to get modern education besides learning Islamic moralities.

The drama that initially gave the message of an approved submissive woman took the turn of women empowering messages through educating them and upholding moral values. Towards the end of sixteenth episode, sensing its possible messages of empowering women, General Zia administration did not approve the broadcasting of further episodes. The drama serial, disrupted in the middle, ended up in the discontinuation of story and the propagation of morality based social messages. In this context, the views of drama director, Shaukat Zain-ulAbidin, are pertinent to fathom the whole political situation and deserve to be quoted here at length:

The lady who played the role of 'Ashgari' was the head of an NGO and was inclined to strive for equal opportunities of education for all. Taken the impression that the role of Asghari was portraying Benazir Bhutto (who was struggling for same women rights during the same time period), the government officials criticized me that I was relating the personality of Benazir Bhutto with Asghari. Thus, facing pressures from the television administration, I was left with no choice except for discontinuing the broadcasting of further episodes (S. Z. Abidin, Personal Communication, July 8, 2006).

The story of the drama Mirat-ul-Uroos (1988) travels around the juxtaposition of two female characters Akbari and Asghari, who are real sisters. Akbari is uneducated, uncivilized and rude, so is not honored in the family of her own and that of her husband. Whereas Asghari was civilized, educated and courteous and was honored in her family as well as in her inlaws. That is why she was considered a personality of being followed. In the beginning of 
drama serial, narrator explains that this story is more than a century old but still it is a piece of advice for women education and training. (Episode 1, 0:55)

Akbari appears as a character having negative attitude towards others. The boundless love and favor of her grandmother carves out her arrogant and overbearing. She remains far away from education and training of moral and religious values even the housekeeping; she wastes her time in idle pleasures. In the culture of the sub-continent, it is assumed that the recklessness of a young boy or a girl can be fixed by getting him/her married. In case of Akbari this idea does not prove right. Her marriage brings more troubles. She quarrels with her husband; becomes rude with her in-laws; laments over joint family system and finally starts living in a separate rented house. Her attitude remains rude with everyone even when her husband Muhammad Aqil advises her to have acquaintance with the noble ladies of honorable families of the city instead of having friendship with daughters of uncivilized and illiterate workers of lower class. She bursts up abruptly on her husband saying, "Noble ladies, my foot, you are too teasing and hurting me like my mother. She always reproached me like you" (Trans. Episode 2, 12:31). Then she starts yelling and cursing her parents by saying, "God may punish my parents who pushed me in a hell. All of you had started your efforts to tease me at any cost; May I die and may you take away my funeral" (Trans. Episode 2, 12:31).

Akbari is portrayed as an aggressive, loud, authoritative, stubborn and foolish girl. The underlying message is to explain the basic responsibilities of a woman. N. Hussain (1996) describes these responsibilities as a submissive, good housekeeper, careful with money, obedient, devoted to the interests of the family, and often a supplicant for her husband's love/attention. This message aligns with the main premise of the dictatorial regime. In the support of this message, the drama further shows that as Akbari was not familiar with cooking and other household tasks so it boosts up her expenditures. Her profligacy and irresponsible attitude leads her family to disaster. She is named Mizaaj Dar Bahoo (Discourteous daughter-in-law) by her in-laws.

The peculiarities of Akbari's younger sister Asghari are quite opposite. Right from the first establishing shot, her role reflects all those characteristics which a Pakistani society wants to see in a 'good woman'. Her entry is very dramatic; with a background voice of 'Aazan' (Call 
for prayer), the camera focuses the flame of an oil lamp placed in an alcove and gradually zoom-out to a long-shot. Ashgari opens the door and comes out in a conventional dress with properly covered head with a big scarf. She blows out the lamp and tugs up her sleeves of her loose fit dress for 'wadoo' (ablution). Then she pulls out water from the well and pours in the bucket. Camera changes the angle with a dissolve, her mother and grandmother enter in traditional dresses at the same time with covered heads. She greets them 'Assalam-oAlaykum' and stretches a prayer-mat. The scene is cut here and the next is back-shot of both mother and grandmother, sitting for wadoo; she picks up lota (water vessel) and helps them pouring water on their hands. Scene changes, and as a contrast camera focuses her sister Akbari's face who is still sleeping in her bed (Episode 1, 1:40). In this scene director has registered Asghari's character as a responsible practicing Muslim girl, and a respectful and obedient daughter who dresses traditionally. Asghari appears in a positive and traditional role. She has studied religion along with the necessary education. Her father works outside the city but she always gets in touch with him by writing letters and seeks his guidance on different family matters. Furthermore, she is fully expert in domestic tasks like tailoring, cooking and housekeeping. Not only her family members but neighbors also admire her respectful and humble attitude. It was Asghari's judicious thinking that she refused to accept dowry more than that of Akbari's to avoid bitterness. After her marriage she was treated with veneration by her in-laws due to her cooperative and loving attitude. Ahmed clearly bifurcates his characters into two groups i.e., good and bad. Those who are good and wellmannered are the incarnate of nobility and politeness, those who are bad and uncultured are like the devil. He has no concept of normal human character who possesses good and bad characteristics simultaneously even in the society.

\section{Conventionality in Dresses}

In both dramas, the concept of Charad and Chardiwari is predominating. "The emphasis on veil has been a constant in the Pakistani woman's tradition" (Talib \& Idrees, 2012; p. 31). This is well-thought-out that women will be safe and secure if they remain within the boundaries of their homes. The etymology of the word 'Aurat' which is used for woman in Udru language also reflects the patriarchal approach. This word is derived from Arabic word 'awrah' or awrat which has several meanings including weakness, imperfection and nakedness (Intimate parts in Islam, n. d.). So it is assumed that woman needs the cover and protection of a male and a garb to hide her nakedness. 
In 1977 when the policy of PTV took a U-turn with the change of the government, we find the girls enveloped in dupattas on screen. Zia used to watch most of the PTV programs in evenings and sometimes conveyed his opinion by calling TV center (Hasan, 2000, p. 202). In 1982 once he called the producer of 'Ankahi' drama serial and 'advised' him that all male and female characters in the play should appear in conventional dresses (kameez and shalwar) and only the bad guys should be shown in western attire. Although he changed this policy sometime later however, he did ask PTV to stop women from appearing in saris (Parach, 2017, p. 5). Women used to wear pants or jeans in combination with their eastern garments but no female in any type of western dress was shown on screen. It was the tough task for TV directors to picture modern and urban characters different from rural ones without using dialogues. In the drama serial Waris, we found the application of the same policy. There are 99.5 percent characters that have dupatta (head-covering) and the remaining 0.5 percent without dupatta characters have valid excuses for that type of dressing. In Pakistani culture, Chadar (Shawl) or dupatta (head-covering) epitomizes a woman's strong character. In dramas this element is used to differentiate good and evil. All the submissive, religious female characters are shown with covered head to express the positivity of their characters. Covering or hiding face with a veil also symbolizes the honor and respect of a woman. It separates an elite and respected woman from those of working lower class (kammi). In Punjabi and Sindhi culture, women who particularly belong to zamindar (landlords) and pir (faith healer) families are supposed to observe strict purda (hijab). The character of Chaudhry Niaz's wife represents the same group of women who are bound to follow these rituals. Face veiling from a relative with whom you don't have any bloodrelation is a common custom in some traditional families which is also projected in these dramas. In Waris when Dilawar's mother talks to his uncle she stretches her dupatta and covered her face. Similarly, in Mirat-ul-Uroos, Asghari and her maternal grandmother do the same while talking to Asghari's father-in-law.

\section{Women's Primary Job}

In TV dramas, women are mainly portrayed in domestic roles. Their primary responsibility is to arrange and manage the house. All household tasks come under the job description of woman. Masculinity does not permit male characters to help women in housekeeping and childcare activities. These activities are considered typically feminine tasks. In mostly rural, traditional and patriarchal settings these tasks are considered beneath the dignity of a male. A 
man is considered head of the family and his primary responsibility is to earn a living and make arrangements of food and shelter for his family. These ideas are endorsed in both selected dramas. The male characters of Ch. Hashmat, Ch. Yaqoob, Niaz and Anwar in Waris and Door Andash, Muhammad Fazil, Kamil and Aaqil in Mirat-ul-Uroos are all dominating characters. And they are portrayed as head of their families respectively, and without their consents the females of their families are not supposed to go anywhere.

Staying within the home is a sign of woman's good character while strong professional women are often cast as villains (Talib \& Idrees 2012, p32). In Mirat-ul-Uroos, housekeeping is projected as a major qualification of woman. In a certain scene, Muhammad Aqil tries to convince his mother for the marriage of his younger brother Kamil and Asghari. He praises her in following words:

It is not easy to locate such a well-mannered and beautiful match; she is unique and matchless in thousands of girls. She, I think is a gift of God. So don't worry and go ahead for her marriage with Muhammad Kamil. I also confirm Asghari's abilities of housekeeping and her respect for elders; be sure that Asghari has no match with my wife Akbari. (Trans; Episode 2, 3:45-4:15)

After the marriage Asghari quickly took over of all household responsibilities and proves herself to be a good wife by using her talent of cooking, tailoring and caring of other family members.

Similarly in Waris, Zakia plays a positive major role in the drama. She is shown as a school principal but only a few shots showcase her working life. Usually throughout the drama she stays home and takes care of her son. Her representation as a working professional is quite weak. Her image appears as Farukh's mother. This essentially means that her son yields her identity. In other words, her identity is represented as a mother of a male figure and not as a school principal. The stereotype of woman can be seen in Zakia's role that she is a frail creature; she is always in need of a male help; she cannot live independently because she is not strong enough to manage the house and outside responsibilities or face the criticism of others. After the death of her husband, she lives with her only child. In the following dialogue, she misses the companionship of her husband and describes her sufferings as a 
widow. It also points out the realization of her major responsibility, which is the upbringing of her son: "I am guarding his (husband) gift (son) for the last 22 years. I spent these past years under a heavy slab of widow-ship, which has ground my bones into powder, but it seems that my trial is not over yet" (Trans. Episode 4, 27:40 - 28:02).

Although she is an educated and professional woman and lives in her house, but she is dependent on Yaqoob, who is a younger brother of her husband. In a dialogue with Yaqoob she says, 'I cannot imagine taking any step without your consultation' (Trans. Waris, Episode $1,28: 01-28: 20)$

Zohra also represents typical village housewife whose major responsibilities are housekeeping and providing care for children. There are no working female characters who are portrayed as free from childcare or male dependence. During the entire period of Islamization, liberal writing style was not welcomed, so only those writers who follow the policy were asked to write for the Television industry. They wrote mostly on family issues, highlighting those Islamic values which are not incongruous with tradition and culture. Some dramas are adaptations of popular Islamic novels like Akhri Chatan (The Last Rock), Shaeen (Falcon) and Mirat-ul-Uroos (The Bridal Mirror), which showcase Islamic history and oriental values. A TV dramatist Fatima S. Bajia mentioned that many writers who were associated with PTV became so habitual of this policy that these values have now become the part of their personalities (F. Bajia, Personal Communication, November 18, 2006). She herself continued that legacy even after the end of the martial law.

\section{Conclusion}

The interpretation of drama analysis confirms all three assumptions: (i) Depiction of women's submissive and acquiescent attitude towards male family members, (ii) women as primary caregiver for children, and (iii) conventionality in female dresses. Drama analysis reveals that the above-mentioned three attributes were projected as qualifications for being good women. I examined 419 scenes altogether in which women were portrayed in different ways. Out of these 419 scenes, women are represented in acquiescent and submissive roles in 314 scenes. Showing acquiescent attitude towards male family members, these dramas portray obedience as a woman's qualification. Thus, they relay an implicit message of obedience that women should follow. Submissiveness is an attribute that serves to be a 
parameter to judge a woman's character and morality even today. Being rude, talking back and questioning the authority of a male family member is not appreciated for a woman in Pakistani society. This is a general understanding in Mulsim culture that husbands have a degree of superiority on their wives. So women are supposed to be submissive and obedient to them. Although this concept is challenged by a Muslim female scholar Riffat Hassan in $1999,{ }^{2}$ the majority of Muslim population still follows the concept of male dominance. Nevertheless, the analysis of dramas unveils that dramas in the Zia period reinforced these submissive roles.

Generally, Muslim cultures are rife with examples where oppression against women gets the cover of religion. The enactment and extension of cultural norms of male chauvinism is an example. It appears that in the portrayal of a 'good Muslim woman' rhetoric, some drama producers had inclinations to present cultural, patriarchal and non-religious norms under a religious label. Mumtaz and Shaheed (1987) mentioned that during the period of Islamization, a large number of customs, traditions, and cultural practices, which in fact violated Islamic injunctions, were being justified by recourse to Islam. These acts by Zia government encouraged trends among communities in Pakistan whereby people used religion to maneuver their personal interests. In other words, Zia's Islamization period fanned a general tendency of lip servicing to Islam and using this for one's own benefits. The exploitation of religion for one's personal benefits is common in Pakistan today.

While talking about women exploitation in the name of religion a TV dramatist, Kalanchvi mentioned that interior Sindh, southern Punjab, and tribal areas of Pakistan are the places where women are chained by many social, economic and religious complexities. Marriages with the Holy Quran, watta satta ${ }^{3}$ marriages, polygamy, early marriages and honor killings are still common. Some of these marriages are just to usurp the right of inheritance from women (Personal Communication, January 12, 2007). In rural Punjabi culture, it is huge insult for a man if his fiancé marries someone else. Once a girl is associated with a man, she has to marry him but if she breaks the bond and marries another guy, she actually triggers a conflict between two families. Consequently, this conflict ends up with a number of murders.

\footnotetext{
${ }^{2}$ See Hassan R. (1999)

${ }^{3}$ In watta satta marriage, the sister of bridegroom is bound to marry with bride's brother.
} 
As we see in drama serial Waris, Fateh Sher's wedding costs the lives of two people, Sikander and a brother of Fateh Sher.

The policy of 'divide and rule' (that British once employed) can be identified in Zia administration's politics, too; Zia government used it to control half of country's population (women) by using aforesaid religio-cultural tactics. Gazdar (1997) mentioned that, "The army junta encouraged and covertly supported sectarian and ethnic groups in order to counter antigovernment political movements. The policy of 'divide and rule' gave birth to armed conflicts between various factions all over the country" (p.154). Although Gazdar's argument does not entail feminist politics that Zia government employed, the argument of divide and rule is pertinent to the situation of feminism, too. This political tactic damaged the cultural and religious fabric of Pakistani society. The generation, which was groomed and trained during the period of 'Islamization' is now resisting the return to modernity. That is why it is important to consider the rhetoric generated during Islamization period. This paper is an attempt to unpack that rhetoric.

In this study, 379 scenes portray women as nonprofessional housewives whereas conventionality is observed in 95 percent female dresses. These female characters prefer to stay at home and live non-professional lives. They take care of their houses and do not work for earning. In this category I included all those unmarried young girls who stay at home with their parents. Thus, these dramas convey a strong message that the major responsibility of women is to stay home and provide care to their children. In drama serial Waris, the only female character, Zakia, who is projected as a school principal, also fulfills her responsibility as child caregiver. Similarly, jobs like cooking, sewing, housekeeping and raising children are associated with female characters.

The slogan of Chadar aur Chardiwari appeared to be one of the main agendas of Islamization which is evident in TV dramas. This agenda was propagated quite well through the dramas. The women portrayal of Pakistani TV dramas of the same period explains a lot about the oppressed atmosphere of the country which pushed women to stand for their rights. As a result, strong feminist activism can be seen in 1980s against issues of inequality, segregated education, Hijab and inheritance, but open discussions on these issues were tabooed. Old traditional customs and religion were intertwined in such a way that the cultural 
values overcome the true spirit of Islam. Thus, in order to understand the circumstances of Muslim women, it is imperative to encompass the respective region's historical and political reasons (as Abu-Lughod (2016) would argue). Pakistan is entangled in complex layers of power, most of which have been at work under the cover of religion. It is very difficult to shake this religio-cultural-political dogma, which has been used by governments to control different groups of public. "Talban's Afghanistan and courts in Nigeria and Pakistan reflect, patriarchal interpretations of the past and tribal custom have proven a formidable obstacle and a source of oppression and injustice" (Esposito 2003, p. 48). Esposito's argument regarding patriarchal interpretations is completely apt here.

This analysis of discourse in dialogues, roles assigned to women, and the ways of addressing them in dramas during Islamization period depict highly conservative images of Pakistani women. Thus, I argue that this kind of rhetoric has a significant role in the provision of an analyzing tool for a woman's conformity with established norms. However, examining the impact of this rhetoric on Pakistani population is beyond the focus of this paper; yet it could be a future research project. Progressive writers, women rights activists and other organizations are actively working in Pakistan to fight against patriarchal fundamentalism and conservativism but still much needs to be done in this regard. 


\section{References}

Author. (2010). PTV Urdu Drama Serials: A Critical And Analytical Study from 1970-2000

(Unpublished doctoral dissertation). Islamia University of Bahawaplur, Pakistan.

Abidin, S. Z. (Producer). (1988). Mirat-ul-Uroos [Television drama serial]. Lahore, Pakistan: Pakistan Television Corporation.

Ali, G. (Producer). (1979). Waris [Television drama serial]. Lahore, Pakistan: Pakistan Television Corporation.

Aslam, I. \& Ali, A. (2009). 'Media Matters in Pakistan' Meddle East Report No. 251,

Pakistan under pressure pp. 32-36

Chomsky, N. (1997). Media Control: The Spectacular Achievements of Propaganda. New York, NY: Seven Stories Press.

Esposito, J. L. (2003). Great World Religion: Islam. Chantilly, VA: The Teaching Company.

Gazdar, M. (1997). Pakistan Cinema 1947-1997. Karachi: Pakistan, Oxford University Press.

Haqqani, H. (2005). Pakistan Between Mosque and Military. Washington, DC: Carnegie Endowment for International Peace.

Haqqani, H. (2013). Magnificent delusions : Pakistan, the united states, and an epic history of misunderstanding. Retrieved from https://ebookcentral.proquest.com

Hasan, B. (2000). Uncensored: An eyewitness account of abuse of power and media in Pakistan. Karachi, Pakistan: Royal Book Company.

Hassan, R. (1999). Feminism in Islam. In A. Sharma \& K. K. Young (Eds.), Feminism and World Religions (pp. 248-278). New York, NY: State University of New York Press.

Hijari, N. (2015). Midnight's Furies: A deadly legacy of India's partition. Boston, MA: Houghton Mifflin Harcourt Publishing Company.

Hussain, S. A. (2015). Power Failure: The Political Odyssey of a Pakistani Woman.

Karachi, Pakistan: Oxford University Press.

Hussain, N. (1996). Television Drama. In M. Malik, \& N. Hussain (Eds.), Reinventing

Women: Representation of Women in the Media During the Zia Years (pp. 22-42).

Lahore, Pakistan: Simorgh Women's Resource and Publication Centre.

Intimate parts in Islam. (n.d.). Wikipedia. Retrieved from

https://en.wikipedia.org/wiki/Intimate_parts_in_Islam

Jaffrelot, C. Ed (2002). Pakistan: Nationalism without Nation?, London: Zed Books Ltd.

Jala, A. (1985). The Sole Spokesman: Jinnah, The Muslim League and Demand for Pakistan,

London: Cambridge University Press. 
Jalal, A. (2013). The pity of partition : Manto's life, times, and work across the IndiaPakistan divide, Princeton: Princeton University Press.

Jamal, A. (2013). Jammat-e-Islami Women in Pakistan: Vanguard of a New Moernity?, Syracuse New York: University Press.

Maskiell, M. (1984). The Impact of Islamization Policies on Pakistani Women's Lives (Unpublished working paper No 69) Montana State University, Bozeman MT.

Mumtaz, K. and Shaheed, F. (1987). Women of Pakistan: Two Steps Forward, London: One Step Back, Zeb Books Ltd

Lawrence Z. (2003). Pakistan: at the Crosscurrent of History, Oxford: Oneworld Publications

Naqvi, S. (2017, August 18). This is very much Zia's Pakistan, the most influential man after Jinnah. Dawn. Retrieved from https://www.dawn.com/news/1352139/this-isvery-much-zias-pakistan-the-most-influential-man-after-jinnah

Paul, T.V. (2014). The Warrior State: Pakistan in the Contemporary World, New York: Oxford University Press.

Paracha, N. F. (July 02, 2017). "Disco and the Dictator", Dawn Retrieved from https://www.dawn.com/news/1342639/smokers-corner-disco-and-the-dictator

Rashid, A. (2012). Pakistan on the Brink: The Future of America, Pakistan and Afghanistan, London: Viking Penguin.

Shah, S. M. (2014). Bhutto Zia and Islam, Retrieved from www.Bhutto.Org.

Saigol, R. (2016). Feminism and the Women's Movement in Pakistan: Actors, Debates and Strategies, Retrieved from http://library.fes.de/pdf-files/bueros/pakistan/12453.pdf

Talbot, I. (1998). Pakistan: A Modern History, London: Hurst \& Company.

Talib, S. \& Idrees, Z. (2012). Pakistani Media and Disempowerment of Women. In Carilli, T. \& Campbell, J. (Eds.), Challenging Images of Women in the Media: Reinventing Women's Lives (pp. 29-33). New York City, NY: Lexington Books.

UNE Center for Global Humanities [Username]. (2015, Nov 30). Ayesha Jalal [Video File]. Retrieved from https://www.youtube.com/watch?v=syTyfvMhlU4\&t=1920s Zia, A. S. (2009). The reinvention of feminism in Pakistan. Feminist Review, 91, 29-46. 